УДК $544.421: 546.57: 544.774 .4: 541.182 .4 / .65$

\title{
SYNTHESIS OF SILVER NANOPARTICLES USING THE RHAMNOLIPID BIOCOMPLEX OF MICROBIAL ORIGIN
}

\author{
L. Bazylyak ${ }^{1 *}$, A. Kytsya ${ }^{1}$, O. Karpenko ${ }^{1}$, \\ A. Prokopalo ${ }^{1}$, T. Pokynbroda ${ }^{1}$, A. Mazur ${ }^{2}$, O. Kuntyi ${ }^{2}$ \\ ${ }^{1}$ Department of Physical Chemistry of Fossil Fuels \\ Institute of Physical Organic Chemistry and Coal Chemistry \\ named after L. M. Lytvynenko, National Academy of Sciences of Ukraine \\ Naukova Str., 3a, 79060 Lviv, Ukraine; \\ ${ }^{2}$ Department of Chemistry and Technology of Inorganic Substances \\ Lviv Polytechnic National University, \\ Bandery Str., 12, 79013 Lviv, Ukraine \\ e-mail: bazyljak.L.I@nas.gov.ua
}

Silver nanoparticles (AgNPs) have been synthesized by "green synthesis" using the silver nitrate as precursor and surface-active rhamnolipid biocomplex - product of microbial synthesis of the strain Pseudomonas sp. PS-17 as reducing agent and stabilizer. Kinetics of AgNPs formation was monitored by UV/vis spectrometry. It was found that the reaction is carried out without the induction period indicating the heterogeneous nature of AgNPs nucleation. Using the transmission electron microscopy it was found that obtained silver sol is consisted of small nanoparticles with diameter $3.6 \pm 2.0 \mathrm{~nm}$. Antimicrobial activity of obtained AgNPs against Agrobacterium tumefaciens was investigated and it was found that the minimum bactericidal concentration is equal to $0,27 \mu \mathrm{g} / \mathrm{mL}$.

Keywords: silver nanoparticles, biosurfactants, kinetics, transmission electron microscopy, antimicrobial activity.

DOI: https://doi.org/10.30970/vch.6102.404

\section{Introduction}

Over the past few decades, metal nanoparticles less than $100 \mathrm{~nm}$ in diameter have made a substantial impact across diverse biomedical applications, such as diagnostic and medical devices, for personalized healthcare practice. In particular, silver nanoparticles (AgNPs) have great potential in a broad range of applications as antimicrobial agents, biomedical device coatings, drug-delivery carriers, imaging probes, diagnostic and optoelectronic platforms, since they have discrete physical and optical properties and biochemical functionality tailored by diverse size- and shape-controlled AgNPs. Silver nanoparticles have been investigated extensively due to their superior physical, chemical, and biological characteristics, and their superiority stems mainly from the size, shape, composition, crystallinity, and the structure of AgNPs compared to their bulk forms [1-5]. Recently in the literature, there have been reports of AgNPs obtaining in different biological

(c) Bazylyak L., Kytsya A., Karpenko O. et al., 2020 
L. Bazylyak, A. Kytsya, O. Karpenko et al.

solutions via the so-called "green methods", for example, using plant extract [6-10] and supernatants obtained from bacterial [11-15] or fungus cultures [16, 17]. Several studies reported the synthesis of AgNPs using green, cost effective, and biocompatible methods without the use of toxic chemicals via biological methods. In this green chemistry approach, several bacteria, including Pseudomonas stutzeri AG259 [18], Lactobacillus [19], Bacillus licheniformis [20], Escherichia coli [21], Brevibacterium casei [22], plant extracts such as Allophylus cobbe [23], Artemisia princeps [24], Typha angustifolia [25] were used. In addition to these, several biomolecules, such as biopolymers [26], starch [27], fibrinolytic enzyme [28], and aminoacids [29] were used. Biological entities could act simultaneously as reducing and stabilizing agents. Increasing attention to the biological synthesis of AgNPs can be attributed to environmental and economic reasons. Green synthesis of AgNPs with naturally occurring reducing agents could be a promising method to replace more complex physiochemical syntheses since the green synthesis is free from toxic chemicals and hazardous byproducts and instead involves natural capping agents for the stabilization of AgNPs. Use of biological agents seem to provide controlled particle size and shape, which is an important factor for various biomedical applications [30]. The other advantages of biological agents are the availability of a vast array of biological resources, a decreased time requirement, high density, stability, and the ready solubility of prepared nanoparticles in water. Biogenic surfactants are one of promising agents for the development of nanocomposites, they are ecologically safe alternative to toxic chemicals. The most known biosurfactants are rhamnolipids, which represent by themselves the low molecular weight secondary metabolits of bacteria genera Pseudomonas. Such biosurfactants were obtained in the Department of Physical Chemistry of Fossil Fuels of the Institute of Physical Organic Chemistry and Coal Chemistry named after L. M. Lytvynenko of the National Academy of Sciences of Ukraine. The strain Pseudomonas sp. PS-17 synthesizes extracellular mono- and dirhamnolipids and polysaccharide of alginate nature. Rhamnolipids and polysaccharide form surface-active complex at the ratio $4: 1$, so-called the rhamnolipid biocomplex (RBC) [31].

Recently it was shown that $\mathrm{RBC}$, being inexpensive and effective product, can be used in environmentally friendly technologies, for example as corrosion inhibitors [32], in agriculture for stimulation of plant growth [33], for remediation of contaminated soils [34], production of detergent compositions. From this point of view, biosurfactants of microbial origin, in particular the rhamnolipid biocomplex are attractive precursors for green synthesis of metallic nanoparticles.

That is why herein we present the use of microbial origin rhamnolipid biocomplex for reducing of $\mathrm{Ag}^{+}$ions and stabilization of AgNPs.

\section{Experimental section}

AgNPs have been synthesized in thermostated glass reactor equipped by magnetic stirrer and Dimroth's fluid-cooled condenser. Silver nitrate (Aldrich, $99 \%$ ) was used as a precursor for AgNPs synthesis; rhamnolipid biocomplex (RBC) (microbial origin biosurfactant) was used both as stabilizer and reducing agent. Cultivation of strain Pseudomonas sp. PS-17 was carried out on a rotary shaker, $220 \mathrm{rpm}$, (WL-2000, JV Electronic, Poland), $30{ }^{\circ} \mathrm{C}, 5$ days with an optimized liquid medium using glycerol $(30 \mathrm{~g} / \mathrm{L})$ as a carbon source [35]. RBC was isolated from the cell-free cultural liquid of the strain Pseudomonas sp. PS-17 (from the collection of Department of Physical Chemistry of Fossil Fuels of the Institute of Physical Organic Chemistry and Coal Chemistry named after L. M. Lytvynenko of the National 
Academy of Sciences of Ukraine) via acid precipitation ( $10 \%$ of $\mathrm{HCl}, \mathrm{pH}=3)$ and purified by reprecipitation. Concentration of RBC for AgNPs synthesis was equal to $1 \mathrm{~g} / \mathrm{L}$.

$\mathrm{UV} / \mathrm{vis}$ spectra of AgNPs sols were recorded using the Uv-mini-1240 UV/vis spectrophotometer (Shimadzu, Japan).

The diameters of obtained AgNPs were determined using transmission electron microscopy (TEM) by comparison of the sizes of individual particles with the scales presented on the images. TEM images of the samples were recorded using a JEM-I230 (JEOL, Japan) with an acceleration voltage of $80 \mathrm{kV}$. The samples for TEM investigations were prepared by drying of $5 \mu \mathrm{l}$ of silver sol on the carbon grid at room temperature.

Antimicrobial activity of obtained AgNPs has been evaluated according to their minimum inhibitory concentration $(M I C)$. MIC is the lowest concentration of antimicrobial agents that inhibits test microorganism phytopathogenic bacteria Agrobacterium tumefaciens growth after incubation in a 24-well round-bottom microplate at $37{ }^{\circ} \mathrm{C}$ for 20 hours. In order to determine the minimum bactericidal concentration $(M B C)$ the subcultures are subcultured on agar plates on medium without inhibitors from each tube from the $M I C$ series of studies, after incubation at $37^{\circ} \mathrm{C}$ for 20 hours [36].

\section{Results and discussion}

AgNPs have been synthesized via reduction of $\mathrm{AgNO}_{3}\left(1 \times 10^{-3} \mathrm{~mol} / \mathrm{L}\right)$ by $\mathrm{RBC}$ $(1 \mathrm{~g} / \mathrm{L})$ at $70{ }^{\circ} \mathrm{C} . \mathrm{pH}$ of starting reaction mix was 8.2. Kinetics of reaction was monitored using UV/vis spectroscopy (Fig. 1) that is one of proper techniques for investigation of AgNPs formation [37-40].

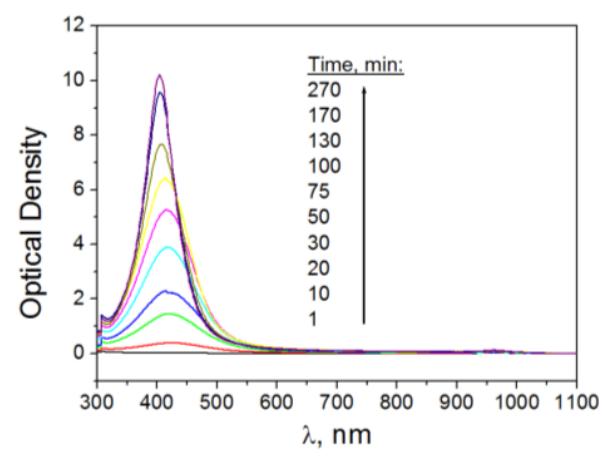

$a$

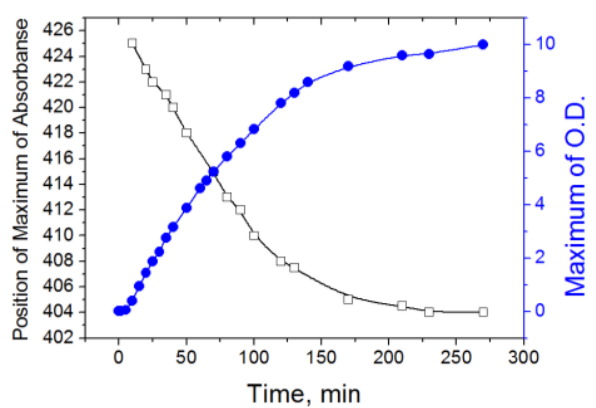

$b$

Fig. 1. The change of UV/vis spectra of silver solution during the synthesis $(a)$ and dependencies of position of maximum of the surface plasmon absorption band (squares) as well as maximum of optical density (circles) on time $(b)$

It was found that the reaction proceeds without the induction period (Fig. 1, b) as well as some opalescence of reaction mixture after adding of $\mathrm{AgNO}_{3}$ was observed. These facts indicate the heterogeneous nature of nucleation of AgNPs that may be caused by interaction of $\mathrm{Ag}^{+}$and acidic group of $\mathrm{RBC}$ followed by the precipitation of polymeric balls saturated with silver ions. This is also indicated by a blue shift of the position of the AgNPs solution absorbance maxima during the synthesis that may be caused by strong interaction of small silver particles and / or nuclei of the AgNPs with the acidic groups of RBC [40, 41]; such interaction is decreased with the growth of particles due to decreasing of ratio of ionized surface silver atoms. 
L. Bazylyak, A. Kytsya, O. Karpenko et al.

Taking into account the heterogeneous nature of nucleation the kinetic curve of AgNPs formation was fitted using the eq. (1) [42, 43] and the rate constant of growth as well as the overall concentration of nuclei were calculated (Fig. 2).

$\ln \frac{a}{1-a}=k\left[\mathrm{Ag}^{+}\right]_{0} t-\ln \left(\frac{\left[\mathrm{Ag}^{+}\right]_{0}}{[\mathrm{~B}]_{0}}\right)$,

here $a=\frac{\text { O.D. }}{\text { O.D. }_{\max }}$ is the conversion of reaction; O.D. is the optical density of solution; O.D.max

is the final optical density of solution; $[\mathrm{B}]_{0}$ is the concentration of nuclei, i. e. the overall concentration (or number) of silver ions that took part in the nucleation process.

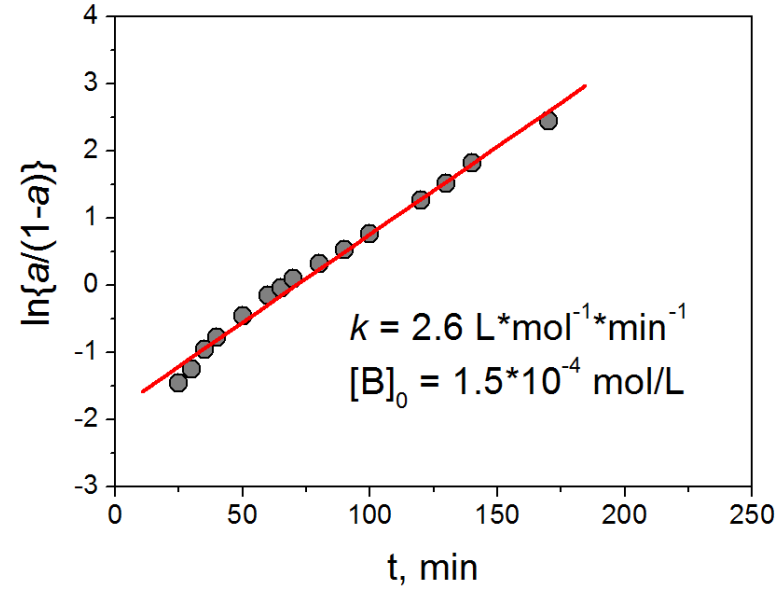

Fig. 2. Linear anamorphose of kinetic curve of the AgNPs formation

Calculated value $[\mathrm{B}]_{0}$ is near 10 times lower than the starting concentration of $\mathrm{Ag}^{+}$. It means that the nucleation is started on the heterogeneities existing in the reaction in a form of polymeric balls of the RBC saturated with the silver ions, but the growth of the AgNPs is caused by reduction of solved $\mathrm{Ag}+$ ions via an interaction with these $\mathrm{Ag}-\mathrm{RBC}$ formations.

Obtained AgNPs were investigated using TEM (Fig. 3) and it was found that synthesized sol is consisted of small particles with mean diameter of $3.6 \mathrm{~nm}$. At the same time, the size distribution of AgNPs is wide and can be fitted by Log-Normal distribution function. Such phenomenon may be caused by heterogeneous nature of the AgNPs nucleation.

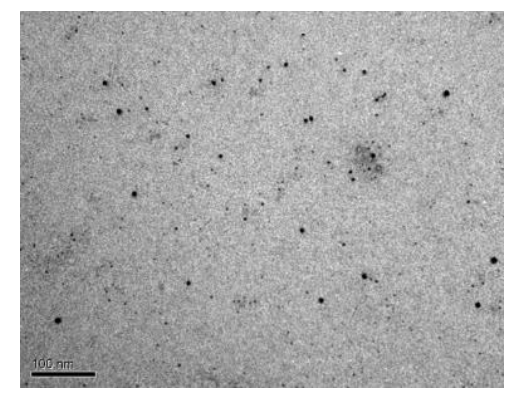

$a$

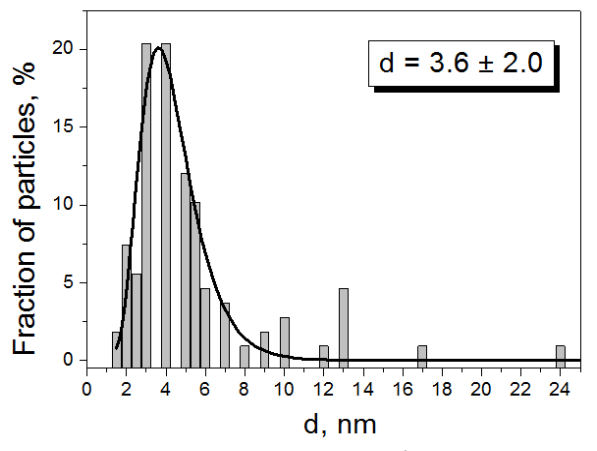

Fig. 3. TEM-image ( $a$ ) and the size distribution $(b)$ of obtained AgNPs 
Taking into account the results of TEM investigations it can be assumed that such small AgNPs are formed via the growth process without the aggregation. That is why the number of obtained AgNPs ([AgNPs]) will be equal to the number of nuclei and such value can be used for the calculation of the number $(n)$ of silver ions that are in the heterogeneous $\mathrm{Ag}-\mathrm{RBC}$ precursor (eq. 2) [39].

For calculation of [AgNPs] the "magic number" concept [44] is acceptable. From the point of view of this concept, 3,6 nm silver nanoparticle represents by itself the cluster, which possess 6 fully filled shells and consist of 923 (Number of atoms $=\left(10 \mathrm{~N}^{3}+15 \mathrm{~N}^{2}+\right.$ $11 \mathrm{~N}+3) / 3, \mathrm{~N}$ is the number of shells) silver atoms. That is why the number of AgNPs in solution (or concentration $[\mathrm{AgNPs}]$ in term mol/L) can be expressed as $\left[\mathrm{Ag}^{+}\right]_{0} / 1000$. Then,

$$
n=\frac{[\mathrm{B}]_{0}}{[\mathrm{AgNPs}]},
$$

and calculated value of $n$ is close to 150 meaning that polymeric RBC ball is saturated by 150 silver ions.

Obtained AgNPs solution was tested as antimicrobial agent against phytopathogenic bacteria Agrobacterium tumefaciens which is the causal agent of crown gall disease (the formation of tumours) in over 140 species of flowering plants (Table). That is why the development of ecological and safe drugs for the plant protection is an actual task.

Antimicrobial activity of biosurfactants and their compositions with AgNPs against Agrobacterium tumefaciens.

\begin{tabular}{|c|c|c|c|c|c|c|}
\hline \multirow{2}{*}{} & \multicolumn{2}{|c|}{$\mathrm{RBC}$} & \multicolumn{2}{c|}{ AgNPs* } & \multicolumn{2}{c|}{ AgNPs (RBC) } \\
\cline { 2 - 7 } & $M I C$ & $M B C$ & $M I C$ & $M B C$ & $M I C$ & $M B C$ \\
\hline Concentration, $\mu \mathrm{g} / \mathrm{mL}$ & 10 & 20 & - & 1 & 0,135 & 0,27 \\
\hline
\end{tabular}

$* M B C$ for AgNPs was taken from [45].

It was found that both MIC and MBC of obtained silver sol are in 8 time lower than the ones for pure RBC and minimum bactericidal concentration of AgNPs is close to $2.5 \cdot 10^{-6} \mathrm{~mol} / \mathrm{L}$ ( or $0.27 \mu \mathrm{g} / \mathrm{mL}$ ) in terms of Ag. Such low MBC (four times lower than it was observed for commercially produced AgNPs [45]) can be explained by high affinity of $\mathrm{RBC}$ to the cell membrane which facilitates the interaction of silver with the microorganisms.

\section{Conclusions}

Solution of silver nanoparticles stabilized by microbial origin rhamnolipid biocomplex has been obtained using "green synthesis" technique. Using TEM it was found that obtained solution containing mainly small AgNPs consisted from ca. $1000 \mathrm{Ag}$ atoms. $\mathrm{Ag}-\mathrm{RBC}$ composition has been tested as antimicrobial preparation and it was observed good efficiency against the test phytopathogenic bacteria Agrobacterium tumefaciens. So, synthesized composition can be considered as promising drug for the protection of plants.

1. Syafiuddin A., Salmiati Salim M. R., Kueh A. B. H., Hadibarata T., Nur H. A. Review of silver nanoparticles: Research trends, global consumption, synthesis, properties, and future Challenges // J. Clin. Chem. Soc. 2017. Vol. 64. P. 732-756. DOI: https://doi.org/10.1002/jccs.201700067 
2. Kumar A., Vemula P. K., Ajayan P. M., John G. Silver-nanoparticle-embedded antimicrobial paints based on vegetable oil // Nat. Mater. 2008. Vol. 7. P. 236-241. DOI: https://doi.org/10.1038/nmat2099

3. Desireddy A., Conn B. E., Guo J., Yoon B., Barnett R. N., Monahan B. M., Kirschbaum K., Griffith W. P., Whetten R. L., Landman U. et al. Ultrastable silver nanoparticles // Nature. 2013. Vol. 501. P. 399-402.

DOI: https://doi.org/10.1038/nature12523

4. Sun Y., Xia Y. Shape-controlled synthesis of gold and silver nanoparticles // Science. 2002. Vol. 298. P. 2176-2179. DOI: https://doi.org/10.1126/science.1077229

5. Atwater H. A., Polman A. Plasmonics for improved photovoltaic devices // Nat. Mater. 2010. Vol. 9. P. 205-213. DOI: https://doi.org/10.1142/9789814317665_0001

6. Krishnaraj C., Jagan E. G., Rajasekar S., Selvakumar P., Kalaichelvan P. T., Mohan N. Synthesis of silver nanoparticles using Acalypha indica leaf extracts and its antibacterial activity against water borne pathogens // Colloids Surf. B. Biointerfaces. 2010. Vol. 76. P. 50-56. DOI: https://doi.org/10.1016/j.colsurfb.2009.10.008

7. Vilchis-Nestor A. R., Sanchez-Mendieta V., Camacho-Lopez M. A., Gomez-Espinosa R. M., Camacho-Lopez M. A., Arenas-Alatorre J. A. Solventless synthesis and optical properties of Au and Ag nanoparticles using Camellia sinensis extract // Mater. Lett. 2008. Vol. 62. P. 3103-3105. DOI: https://doi.org/10.1016/j.matlet.2008.01.138

8. Chandran S. P., Chaudhary M., Pasricha R., Ahmad A., Sastry M. Synthesis of gold nanotriangles and silver nanoparticles using Aloe vera plant extract // Biotechnol. Prog. 2006. Vol. 22. P. 577-583. DOI: https://doi.org/10.1021/bp0501423

9. Amooaghaie R., Saeri M. R., Azizi M. Synthesis, characterization and biocompatibility of silver nanoparticles synthesized from Nigella sativa leaf extract in comparison with chemical silver nanoparticles // Ecotoxicol. Environ. Saf. 2015. Vol. 120. P. 400-408. DOI: https://doi.org/10.1016/j.ecoenv.2015.06.025

10. Bar H., Bhui D. Kr., Sahoo G. P., Sarkar P., De S. P., Misra A. Green synthesis of silver nanoparticles using latex of Jatropha curcas // Colloids Surf. A. 2009. Vol. 339. P. 134-139. DOI: https://doi.org/10.1016/j.colsurfa.2009.02.008

11. Płaza G., Chojniak J., Mendrek B., Trzebicka B., Kvitek L., Panacek A., Prucek R., Zboril R., Paraszkiewicz K., Bernat P. Synthesis of silver nanoparticles by Bacillus subtilis T-1 growing on agro-industrial wastes and producing biosurfactant // IET Nanobiotechnol. 2016. Vol. 10. P. 62-68.

DOI: https://doi.org/10.1049/iet-nbt.2015.0016

12. Gurunathan S., Kalishwaralal K., Vaidyanathan R., Deepak V., Pandian S. R. K., Muniyandi J., Hariharan N., Eom S. H. Biosynthesis, purification and characterization of silver nanoparticles using Escherichia coli // Colloids Surf. B. 2009. Vol. 74. P. 328-335. DOI: https://doi.org/10.1016/j.colsurfb.2009.07.048

13. Shahverdi A. R., Minaeian S., Shahverdi H. R., Jamalifar H., Nohi A. A. Rapid synthesis of silver nanoparticles using culture supernatants of Enterobacteria : A novel biological approach // Process Biochem. 2007. Vol. 42. P. 919-923. DOI: https://doi.org/10.1016/j.procbio.2007.02.005

14. Kalishwaralal K., Deepak V., Ramkumarpandian S., Nellaiah H., Sangiliyandi S. Extracellular biosynthesis of silver nanoparticles by the culture supernatant of Bacillus licheniformis // Mater. Lett. 2008. Vol. 62. P. 4411-4413.

DOI: https:// doi.org/10.1016/j.matlet.2008.06.051 
15. Nanda A., Saravanan M. Biosynthesis of silver nanoparticles from Staphylococcus aureus and its antimicrobial activity against MRSA and MRSE // Nanomed. Nanotechnol. 2009. Vol. 5. P. 452-456.

DOI: https://doi.org/10.1016/j.nano.2009.01.012

16. Vigneshwaran N., Ashtaputre N. M., Varadarajan P. V., Nachane R. P., Paralikar K. M., Balasubramanya R. H. Biological synthesis of silver nanoparticles using the fungus Aspergillus flavus // Mater. Lett. 2007. Vol. 61. P. 1413-1418.

DOI: https://doi.org/10.1016/j.matlet.2006.07.042

17. Bhainsa K. C., D'Souza S. F. Extracellular biosynthesis of silver nanoparticles using the fungus Aspergillus fumigatus // Colloids Surf. B Biointerfaces. 2006. Vol. 47. P. 160-164. DOI: https://doi.org/10.1016/j.colsurfb.2005.11.026

18. Klaus T., Joerger R., Olsson E., Granqvist C. G. Silver-based crystalline nanoparticles, microbially fabricated // Proc. Natl. Acad. Sci. USA. 1999. Vol. 96. P. 13611-13614. DOI: https://doi.org/10.1073/pnas.96.24.13611

19. Nair B., Pradeep T. Coalescence of nanoclusters and formation of submicron crystallites assisted by Lactobacillus strains // Cryst. Growth Des. 2002. Vol. 2. P. 293-298. DOI: https://doi.org/10.1021/cg0255164

20. Kalimuthu K., Babu R. S., Venkataraman D., Bilal M., Gurunathan S. Biosynthesis of silver nanocrystals by Bacillus licheniformis // Colloid Surface B. 2008. Vol. 65. P. 150-153. DOI: https://doi.org/10.1016/j.colsurfb.2008.02.018

21. Gurunathan S., Kalishwaralal K., Vaidyanathan R., Venkataraman D., Pandian S. R., Muniyandi J., Hariharan N., Eom S. H. Biosynthesis, purification and characterization of silver nanoparticles using Escherichia coli // Colloids Surf. B. 2009. Vol. 74. P. 328-335. DOI: https://doi.org/10.1016/j.colsurfb.2009.07.048

22. Kalishwaralal K., Deepak V., Ram Kumar Pandian S., Kottaisamy M., BarathManiKanth S., Kartikeyan B., Gurunathan S. Biosynthesis of silver and gold nanoparticles using Brevibacterium casei // Colloids Surf. B. 2010. Vol. 77. P. 257-262. DOI: https://doi.org/10.1016/j.colsurfb.2010.02.007

23. Gurunathan S., Han J., Park J. H., Kim J. H. A green chemistry approach for synthesizing biocompatible gold nanoparticles // Nanoscale Res. Lett. 2014. Vol. 9. P. 248. DOI: https://doi.org/10.1186/1556-276X-9-248

24. Gurunathan S., Jeong J. K., Han J. W., Zhang X. F., Park J. H., Kim J. H. Multidimensional effects of biologically synthesized silver nanoparticles in Helicobacter pylori, Helicobacter felis, and human lung (L132) and lung carcinoma A549 cells // Nanoscale Res. Lett. 2015. Vol. 10. P. 1-17.

DOI: https://doi.org/10.1186/s11671-015-0747-0

25. Gurunathan S. Biologically synthesized silver nanoparticles enhances antibiotic activity against Gram-negative bacteria // J. Ind. Eng. Chem. 2015. Vol. 29. P. 217-226. DOI: https://doi.org/10.1016/j.jiec.2015.04.005

26. Leung T. C., Wong C. K., Xie Y. Green synthesis of silver nanoparticles using biopolymers, carboxymethylated-curdlan and fucoidan // Mater. Chem. Phys. 2010. Vol. 121. P. 402-405. DOI: https://doi.org/10.1016/j.matchemphys.2010.02.026

27. Kumar B., Smita K., Cumbal L., Debut A., Pathak R. N. Sonochemical synthesis of silver nanoparticles using starch: A comparison // Bioinorg. Chem. Appl. 2014. Vol. 2014. P. 784268. DOI: http://dx.doi.org/10.1155/2014/784268 
L. Bazylyak, A. Kytsya, O. Karpenko et al.

28. Deepak V., Umamaheshwaran P. S., Guhan K., Nanthini R. A., Krithiga B., Jaithoon N. M., Gurunathan S. Synthesis of gold and silver nanoparticles using purified URAK // Colloid Surface B. 2011. Vol. 86. P. 353-358.

DOI: https://doi.org/10.1016/ j.colsurfb.2011.04.019

29. Shankar S., Rhim J. W. Amino acid mediated synthesis of silver nanoparticles and preparation of antimicrobial agar/silver nanoparticles composite films // Carbohydr. Polym. 2015. Vol. 130. P. 353-363.

DOI: https://doi.org/10.1016/j.carbpol.2015.05.018

30. Gurunathan S., Han J. W., Kwon D. N., Kim J. H. Enhanced antibacterial and antibiofilm activities of silver nanoparticles against Gram-negative and Gram-positive bacteria // Nanoscale Res. Lett. 2014. Vol. 9. P. 373.

DOI: https://doi.org/ 10.1186/1556-276X-9-373

31. Pokhmurs 'kyi V., Prystans'kyi R., Shul'ha O., Karpenko O. Quantum-chemical model of a surface-active complex of PS-17 strain // Dopov. Nats. Akad. Nauk Ukr. Ser. B. 1997. Vol. 9 P. 151-154 (in Ukrainian).

32. Zin I. M., Pokhmurskii V. I., Korniy S. A., Karpenko O. V., Lyon S. B., Khlopyk O. P., Tymus M. B. Corrosion inhibition of aluminium alloy by rhamnolipid biosurfactant derived from Pseudomonas sp. PS-17 // Anti-Corrosion Methods and Materials. 2018. Vol. 65. Is. 6. P. 517-527. DOI: https://doi.org/10.1108/ACMM-03-2017-1775

33. Banya A. R., Karpenko O. Y., Lubenets V. I., Novikov V. P., Karpenko O. V. The influence of surface-active rhamnolipid biocomplex and ethylthiosulfanilate on growth and biochemical parameters of plants in oil polluted soils // Biotechnologia Acta. 2015. Vol. 8. No. 5. P. 57-81 (in Ukrainian).

34. Sliwka E., Kotwzan B., Grabas K., Karpenko E., Rutkowski P. Influence of rhamnolipids from Pseudomonas PS-17 on coal tar and petroleum residue biodegradation // Environment Protection Engineering. 2009. Vol. 35. Is. 1. P. 139-150.

35. Yerokhin V., Pokynbroda T., Karpenko O., Novikov V. Study of the growth and synthesis of the target product by the strain Pseudomonas species PS-17 - producent of extracellular biosurfactants // Visn. Natsion. Univers. "Lvivska politehnika". 2006. Vol. 553. P. 124-127 (in Ukrainian).

36. Sotirova A., Avramova T., Stoitsova S., Lazarkevich I., Lubenets V., Karpenko E., Galabova D. The importance of rhamnolipid-biosurfactant induced changes in bacterial membrane lipids of Bacillus subtilis for the antimicrobial activity of thiosulfonates // Curr. Microbiol. 2012. Vol. 65. P. 534-541.

DOI: https://doi.org/10. 1007/s00284-012-0191-7

37. Sandoe H. E., Watzky M. A., Diaz S. A. Experimental probes of silver metal nanoparticle formation kinetics: Comparing indirect versus more direct methods // Int. J. Chem. Kinet. 2019. Vol. 51. Is. 11. P. 861-871.

DOI: https://doi.org/10.1002/kin.21315

38. Kytsya A. R., Reshetnyak O. V., Bazylyak L. I., Hrynda Y. M. UV/VIS-spectra of silver nanoparticles as characteristics of their sizes and sizes distribution // Functional polymer blends and nanocomposites: A practical engineering approach. New York: Apple Academic Press, 2014. P. 231-239. DOI: https://doi.org/10.1201/b16895

39. Kytsya A., Bazylyak L., Simon P., Zelenina I., Antonyshyn I. Kinetics of $\mathrm{Ag}_{300}$ nanoclusters formation: The catalytically effective nucleus via a steady-state approach // Int. J. Chem. Kinet. 2019. Vol. 51. Is. 4. P. 266-273.

DOI: https://doi.org/10.1002/kin.21249 
40. Kuntyi O. I., Kytsya A. R., Mertsalo I. P., Mazur A. S., Zozula G. I., Bazylyak L. I., Topchak $R$. V. Electrochemical synthesis of silver nanoparticles by reversible current in solutions of sodium polyacrylate // Colloid Polymer Sci. 2019. Vol. 297. P. 689-695. DOI: https://doi.org/10.1007/s00396-019-04488-4

41. Slistan-Grijalva A., Herrera-Urbina R., Rivas-Silva J. F., Avalos-Borja M., CastillonBarraza F. F., Posada-Amarillas A. Classical theoretical characterization of the surface plasmon absorption band for silver spherical nanoparticles suspended in water and ethylene glycol // Physica E. 2005. Vol. 27. Is. 1-2. P. 104-112.

DOI: https://doi.org/10.1016/j.physe.2004.10.014

42. Huang Z. Y., Mills G., Hajek B. Spontaneous formation of silver particles in basic 2propanol // J. Phys. Chem. 1993. Vol. 97. Is. 44. P. 11542-11550.

DOI: https://doi.org/10.1021/j100146a031

43. Kytsya A., Bazylyak L. Kinetics of silver nanoparticles formation in the presence of nucleation centers // Proc. Shevchenko Sci. Soc. Chem. Sci. 2017. Vol. XLVIII. P. 56-63 (in Ukrainian).

44. Schmidt A. F., Smirnov V. V. Concept of "magic" number clusters as a new approach to the interpretation of unusual kinetics of the Heck reaction with aryl bromides // Topics in Catalysis. 2005. Vol. 32, No. 1, 2. P. 71-75. DOI: https://doi.org /10.1007/s11244-005-9261-4

45. Wang C., Wang L., Wang Y., Liang Y., Zhang J. Toxicity effects of four typical nanomaterials on the growth of Escherichia coli, Bacillus subtilis and Agrobacterium tumefaciens // Environmental Earth Sciences. 2012. Vol. 65, No. 6. P. 1643-1649. DOI: https://doi.org/10.1007/s12665-011-1139-0

\title{
СИНТЕЗ НАНОЧАСТИНОК СРІБЛА 3 ВИКОРИСТАННЯМ РАМНОЛІПІДНОГО БІОКОМПЛЕКСУ МІКРОБНОГО ПОХОДЖЕННЯ
}

\author{
Л. Базиляк ${ }^{1}$, А. Киця ${ }^{1}$, О. Карпенко ${ }^{1}$, \\ А. Прокопало ${ }^{1}$, Т. Покиньброда ${ }^{1}$, А. Мазур ${ }^{2}$, О. Кунтий ${ }^{2}$ \\ ${ }^{1}$ Відділення фізико-хімї горючих копалин \\ Інституту фізико-органічної хімії і вуглехімії ім. Л. М. Литвиненка \\ Національної академії наук України \\ вул. Наукова, 3а, 79060 Львів, Украӥна; \\ ${ }^{2}$ Національний університет “Львівська політехніка” \\ вул. Ст. Бандери, 12, 79013 Львів, Украӥна \\ e-mail: bazyljak.L.I@nas.gov.ua
}

Наночастинки срібла, стабілізовані біосурфактантом мікробного походження, отримано відновленням нітрату срібла в присутності рамноліпідного біокомплексу, який синтезований культурою Pseudomonas sp. PS-17. Кінетику формування наночастинок срібла досліджено 3 використанням спектроскопії в УФ/видимому діапазоні. 3'ясовано, що процес відбувається без індукційного періоду, що свідчить про гетерогенний характер зародження нової фази. Висловлено припущення, що формування гетерогенностей у реакційному середовищі відбувається завдяки взаємодії іонів срібла з карбонільними групами рамноліпідного біокомплексу, 
L. Bazylyak, A. Kytsya, O. Karpenko et al.

ISSN 2078-5615. Visnyk of the Lviv University. Series Chemistry. 2020. Issue 61. Pt. 2

що спричиняє зменшення його розчинності у воді. На основі експериментальних даних розраховано значення константи швидкості росту наночастинок та ефективної концентрації зародків. 3 використанням трансмісійної електронної мікроскопії визначено середній діаметр отриманих наночастинок, який становить $3,6 \pm 2,0$ нм. На основі порівняння результатів трансмісійної електронної мікроскопії та кінетичних даних розраховано кількість іонів срібла в зародку. Досліджено антимікробну активність отриманого розчину наночастинок срібла та визначено його високу ефективність проти грам-негативних облігатно-аеробних паличкоподібних грунтових бактерій Agrobacterium tumefaciens, які є відомим патогеном понад 140 видів рослин і викликають хворобу корончастих галлів. Отже, синтезовану композицію можна розглядати як перспективний препарат для захисту рослин.

Ключові слова: наночастинки срібла, біосурфактанти, кінетика, трансмісійна електронна мікроскопія, антимікробна активність.

Стаття надійшла до редколегії 30.10.2019

Прийнята до друку 19.02.2020 